\title{
Electrons collide
} at Stanford

\section{Berkeley}

AFTER a year of delays due to budget cuts and technical difficulties, Stanford's Linear Collider (SLC) should soon be producing $Z^{0}$ particles, carriers of the nuclear weak force. On 18 April, beams of electrons and positrons 16 micrometres in diameter were for the first time made to pass through each other in the collider's detector hall. Combined beam energies of $93 \mathrm{GeV}$, enough for $\mathrm{Z}^{0}$ production, were achieved, and within 2 months scientists at the Stanford Linear Accelerator Center (SLAC) expect to begin experiments.

The SLC, which was built for $\$ 115$ million, is the ultimate refinement of high-energy linear electron-positron colliders, and is a rival to conventional storage rings, which become prohibitively expensive at energies of greater than $100 \mathrm{GeV}$. It uses Stanford's linear accelerator to accelerate bunches of positrons and electrons, which are then guided around opposing arcs that focus them on a collision course with each other.

Gramm-Rudman budget cuts last year slowed the commissioning process, as did unexpected difficulties due to broadening of the particle beams as they travel through the collider arcs. The problem was hard to correct because of the complex geometry of the arcs, which for reasons of economy do not lie in a plane but were built to follow the contours of the hillside. The beams were finally condensed and focused by adjustment of about half of the 500 guiding magnets.

Before experiments can begin, the beam intensity must be doubled, and adjustments may also be necessary to minimize background radiation, but neither task represents a major hurdle, said SLAC spokesman Michael Riordan. The collider is expected to yield only a few $Z^{0}$ particles a day initially, and an optimal beam diameter of 3 micrometres, yielding $3,000 \mathrm{Z}^{0} \mathrm{~s}$ per day, may not be reached for several years.

If it meets no further snags, SLC should have the first chance to determine the mass, lifetime and decay modes of the $Z^{0}$. More detailed study of it is likely to be done at CERN's large electronpositron collider (LEP), expected to produce $Z^{0}$ particles at five times SLC's optimum rate.

Marcia Barinaga

\section{Glaxo award}

Nature's editor John Maddox has been awarded the Glaxo Science Writers' Award for "Best Article or Series of Articles in a Specialist Journal on a Science Subject". The award was given for the "Science in the Soviet Union" supplement in Nature 29 October 1987.

\section{Anti-nuclear emotions raised by Bavarian reprocessing plant} \section{Munich}

Marathons, balloons, films, and violent and non-violent protests are only some of the means that West German anti-nuclear activists have used to demonstrate their opposition to the Wackersdorf nuclear reprocessing plant. And last week, opponents presented the Bavarian Environment Ministry with petitions containing over 700,000 signatures gathered in West Germany, Austria and even the United States, calling for a halt in construction of the plant.

Two legal challenges being considered by the Federal Constitutional Court may prove more effective than all the other protests combined in shutting down Wackersdorf. The plant is due to begin operation in 1996 at an estimated final cost of DM 7,400 million.

The petitions are likely to present logistical problems for the Bavarian Environment Ministry. The ministry is required to hold a public meeting for opponents, licensing authorities and DWK, the firm constructing Wackersdorf. If even 10 per cent of the opponents were to come, the meeting might have to be held in Munich's Olympic Stadium.

One legal challenge might give the opponents a chance to stop the construction of Wackersdorf by referendum. Bavaria's highest court had rejected a referendum on the location of the plant, declaring that the decision rests with the federal government. The opponents claim the Bavarian court contained too many members of a single political party, the Christian Social Union, which generally supports the nuclear programme.

The second case before the federal court concerns a January decision by a Bavarian court that declared the development scheme for Wackersdorf null and void because of insufficient protection of the population against radiation in the event of an accident. Construction has continued, however, because the Bavarian Interior Ministry ruled that the individual construction licences for sections of the plant remain valid even if the overall scheme is invalidated.

Wackersdorf opponents also challenge the decision by another federal court to allow construction on the basis of the construction licences, despite the lack of the necessary "nuclear licence" for the plant. Opposition leader Armin Weiss (Green Party), a chemistry professor at the University of Munich and a member of the Bavarian parliament, denounced the inconsistencies in the rulings as "Orwellian doublethink."

Weiss questions the logic behind building a reprocessing plant when it appears West Germany may never complete its nuclear fuel cycle. Reprocessing nuclear fuel elements is more expensive and less safe than putting spent fuel rods directly into "permanent storage sites", he said. The only reason to put Wackersdorf into operation. Weiss said, would be as a source of plutonium for nuclear weapons. (West Germany is prevented from possessing such weapons by the international nuclear Non-Proliferation Treaty, which lapses in 1995.)

The West German government stands by its nuclear programme. Marlene Mühe at the Environment Ministry re-

\section{Encouragement needed}

A LACK of motivation is prevalent at East German universities, especially among women in technical fields. This is the conclusion of a survey conducted at the Technical University of Dresden, reported in the magazine Für Dich.

Of university students in East Germany, 54 per cent are women. Even at the Technical University, 40 per cent of students are women, compared with close to nil in the 1950s. They achieve their hardwon places through good grades, but the survey reports that women entering food chemistry or textile technology have only a vague grasp of these fields.

Education researchers find the root of the problem lies in girls being actively discouraged in their interest in technical areas. Schools have succeeded in demystifying the study of mathematics (Für Dich reports that mathematics is the favourite subject of most girls as well as boys), but have done little to encourage women in technical fields.

Aware of the technological challenge presented by the gradual opening of East Germany to the West (see Nature 329, 192; and 330, 510; 1987), the East German Communist Party addressed the issue at its eleventh party congress, reminding schools that they are polytechnic in nature and should behave accordingly.

Steven Dickman

jected Weiss' weapons charge as "absolute nonsense." Environment Ministry official Armin Hagen listed several justifications for Wackersdorf. He said that even without a fast breeder, it makes sense to reprocess spent fuel elements because it saves energy. Furthermore, the reprocessing of fuel elements would save space in permanent storage sites.

But the last reason on Hagen's list for construction to continue is most compelling politically: stopping in mid-1988 would be like "throwing DM 2,000 million out the window". Steven Dickman 